\title{
Substrate selection and oxygen uptake by the lactating mammary gland
}

\author{
BY DERMOT H. WILLIAMSON AND PATRICIA LUND \\ Metabolic Research Laboratory, Nuffield Department of Clinical Medicine, Radcliffe Infirmary, \\ Woodstock Road, Oxford OX2 $6 \mathrm{HE}$
}

AND RHYS D. EVANS

Department of Anaesthetics, Radcliffe Infirmary, Woodstock Road, Oxford OX2 $6 \mathrm{HE}$

\section{Sélection de substrats et consommation d'oxygène par la glande mammaire en lactation}

\begin{abstract}
RÉSUMÉ
Toutes les protéines et tout le lactose, et environ $50 \%$ des acides gras des lipides du lait sont synthétisés par les cellules épithéliales de la gland mammaire. Au pic de la lactation, il y a une demande énergétique élevée auprès de ces cellules pour fournir les substrats circulants (glucose, acides gras, corps cétoniques, triacylglycérols et acides aminés), pour les réactions de biosynthèse, et pour la sécrétion de lait. Le coût d'énergie individuelle le plus élevé est imputé à la synthèse des lactoprotéines. Cette énergie provient en grande partie de l'oxydation du glucose (chez les non-ruminants), et du glucose plus acétate (chez les ruminants). Comme on peut s'y attendre, les taux mesurés de l'extraction d' $\mathrm{O}_{2}$ par la glande en lactation chez le rat in vivo sont plus élevés (d'environ $50 \%$ ) que ceux requis pour les réactions purement de synthèse, et l'absorption $\mathrm{d}^{\prime} \mathrm{O}_{2}$ reste importante lorsque la production de lait est faible (comme chez le rat à l'état de jeûne). Normalement, le principal précurseur de la lipogenèse est le glucose chez le nonruminant, l'acétate et le 3-hydroxybutyrate chez le ruminant. Le glucose est aussi le précurseur du lactose et du glycéride-glycérol. Cependant, la consommation de substrats par le tissu mammaire est très sensible aux modifications de l'alimentation (un régime riche en glucides opposé à un régime riche en graisses, le jeûne), et aux hormones plasmiques (déficience en prolactine ou en insuline). Nous discuterons ici les facteurs susceptibles de contrôler la consommation et la sélection des substrats par la glande mammaire (y compris le flúx sanguin du tissu).
\end{abstract}

The mammary gland is a unique tissue in that during lactation it has a high metabolic rate, yet its biosynthetic products are of no direct benefit to the lactating mother. Indeed, the mammary gland can be considered as a benign, highly regulated tumour (Williamson et al. 1988). Furthermore, because of the drain on the maternal energy supplies, the metabolism of the gland and that of other tissues must be carefully integrated (Bauman \& Currie, 1980; Williamson, 1980). Although there are differences in the type and amounts of substrates utilized by mammary tissue of various species, particularly between ruminants and non-ruminants, the strategies employed in regulating their uptake and utilization are similar. Much of the pioneering work on defining the 
substrates of the mammary gland was carried out over 20 years ago on the lactating goat by Linzell and his colleagues (for reviews, see Linzell, 1968, 1974). More recent work has been directed to the mechanisms that determine fuel selection in response to dietary and hormonal changes. The present contribution concentrates mainly on the mammary gland of the lactating rat, primarily because its biochemical profile is likely to be similar to that of the human and the majority of the recent advances in the regulation of mammary gland metabolism have been made in this species.

\section{SUBSTRATE UTILIZATION}

The uptake and utilization of a substrate by a tissue are governed by several factors, including availability in the circulation, mass of tissue and blood flow to it, transport systems of cells and organelles, activities of key enzymes and the hormonal milieu (Williamson, 1984).

\section{Methodology}

Much of the information on substrate utilization by the lactating mammary gland has been obtained by measurement of arterio-venous differences for the various substrates and determination of blood flow by distribution of ${ }^{3} \mathrm{H}_{2} \mathrm{O}$ or ${ }^{86} \mathrm{RbCl}$ (Chatwin et al. 1969; Hanwell \& Linzell, 1973) or radioactive microspheres (Jones \& Williamson, 1984; Viña et al. 1987) in the gland. In larger animals simultaneous measurements of arterio-venous differences and blood flow can be made in unstressed, conscious animals, a technique not possible with small animals. In these species, such measurements must be interpreted with caution, because stress and anaesthesia may alter blood flow. To overcome these problems, alternative methods have been developed for the rat which allow assessment of mammary gland substrate utilization without knowledge of blood flow, and without anaesthesia. These methods depend on the accumulation of a non-metabolizable product within the gland over a period of time. (For example, deoxy $\left[{ }^{3} \mathrm{H}\right]$ glucose-6-phosphate is used to monitor uptake of glucose (Threadgold \& Kuhn, 1984; Burnol et al. 1987); $\alpha$-amino $\left[1-{ }^{14} \mathrm{C}\right]$ isobutyrate, an analogue of alanine, for uptake of amino acids (Tedstone et al. 1990) or a product which is present in milk, e.g. ${ }^{14} \mathrm{C}$-labelled lipid for utilization of ${ }^{14} \mathrm{C}$-labelled triacylglycerols (Oller do Nascimento \& Williamson, 1986).) In addition, conversion of substrates to fatty acids (lipogenesis) can be measured with ${ }^{3} \mathrm{H}_{2} \mathrm{O}$ (Robinson et al. 1978).

\section{Substrate availability}

A striking feature of lactation in the rat is the considerable increase (up to $300 \%$ ) in food intake (Fell et al. 1963; Cripps \& Williams, 1975) accompanied by a doubling in weight of the intestinal tract (Craft, 1970; Cripps \& Williams, 1975). There is also hypertrophy of the mammary gland and liver. A comparison of a range of substrate concentrations in the arterial blood of two non-ruminants (rat and pig) and two ruminants (goat and sheep) shows that the major differences are in the values for acetate which are approximately 10-fold higher in the latter (Table 1). Delivery of available substrates (and hormones) to the lactating gland is assured by the increase in the cardiac output and in the proportion of blood flow received by the gland (Hanwell \& Linzell, 1973). 
Table 1. Substrate availability in arterial plasma during lactation

\begin{tabular}{|c|c|c|c|c|c|c|c|c|c|}
\hline \multirow[b]{2}{*}{ Species } & \multicolumn{8}{|c|}{ Substrate $(\mathrm{mmol} / \mathrm{l})$} & \multirow[b]{2}{*}{ References } \\
\hline & Glucose & Lactate & Acetate & $\begin{array}{l}\text { 3-Hydroxy- } \\
\text { butyrate }\end{array}$ & $\begin{array}{l}\text { Aceto- } \\
\text { acetate }\end{array}$ & $\begin{array}{l}\text { Triacyl- } \\
\text { glycerols }\end{array}$ & NEFA & $\begin{array}{l}\text { Amino } \\
\text { acids }\end{array}$ & \\
\hline Rat & $4 \cdot 59^{*}$ & $0.93 *$ & $0-25 * \dagger$ & $0-14^{*}$ & $0.20^{*}$ & 0.91 & 0.61 & $4 \cdot 0^{*} \ddagger$ & $\begin{array}{l}\text { Hawkins \& } \\
\text { Williamson } \\
\text { (1972) }\end{array}$ \\
\hline Pig & $6 \cdot 79$ & $1 \cdot 30$ & $0 \cdot 22$ & $0 \cdot 19$ & 0.06 & 0.44 & $0.33 \S$ & $3.5 \S$ & $\begin{array}{l}\text { Spincer et al. } \\
\quad(1969)\end{array}$ \\
\hline Goat & $2 \cdot 52$ & 0.75 & 1.48 & $0-56$ & $<0.01$ & $0 \cdot 29$ & 0.44 & $3 \cdot 1$ & Linzell (1968) \\
\hline Sheep & $4 \cdot 57$ & 0.54 & $2 \cdot 44$ & 0.56 & nd & nd & 0.26 & nd & $\begin{array}{l}\text { Vernon et al. } \\
\quad(1990)\end{array}$ \\
\hline
\end{tabular}

nd, not determined; NEFA, non-esterified fatty acids.

* Measurements on whole blood.

$\dagger$ Buckley \& Williamson (1977).

† Viña et al. (1987).

$\$$ Linzell et al. (1969).

If arterio-venous differences and blood flow to the gland are known, the uptake of circulating substrates can be expressed as the amount extracted per unit time. However, for many purposes, the relative uptake of substrates calculated on the basis of $\mathrm{C}$ atoms (Table 2) is more informative, and does not require knowledge of the blood flow. On this basis two important substrates of mammary gland, in addition to amino acids, are glucose and triacylglycerols in both ruminants and non-ruminants (Table 2). The main difference is that in the rat glucose is a precursor for lipid and lactose synthesis, whereas in the goat it is either converted to lactose or oxidized (Linzell, 1968). Ruminants lack citrate lyase (EC 4.1.3.8) so precluding conversion of glucose to fatty acids; acetate is the main lipogenic precursor in the ruminant. The low (rat) or apparently absent (goat and pig) contribution of NEFA (non-esterified fatty acids) to mammary gland substrate supply (Table 2) must be interpreted with caution because NEFA liberated by the action of lipoprotein lipase (EC 3.1.1.34) on triacylglycerols (chylomicrons or VLDL) may be released to the venous plasma and, thus, result in artefactually-low arterio-venous

Table 2. Substrate utilization by lactating mammary gland

\begin{tabular}{lccc}
\hline \hline & \multicolumn{3}{c}{ Relative uptake by mammary gland $(\%)^{*}$} \\
\cline { 2 - 4 } Substrate & Rat & Pig & Goat \\
\hline Glucose & 20 & 70 & 31 \\
Lactate & $1 \cdot 1$ & 0 & $4 \cdot 3$ \\
Acetate & - & $1 \cdot 1$ & $11 \cdot 0$ \\
3-Hydroxybutyrate & $0 \cdot 7$ & $0 \cdot 4$ & $8 \cdot 6$ \\
Acetoacetate & $1 \cdot 1$ & 0 & 0 \\
NEFA & $11 \cdot 7$ & 0 & 0 \\
Triacylglycerols & 66 & 28 & 45 \\
\hline
\end{tabular}

NEFA, non-esterified fatty acids.

* Expressed as percentages of the total substrate uptake calculated on the basis of $\mathrm{C}$ atoms (e.g. glucose 6 , NEFA 18, triacylglycerols 54). 
differences for NEFA (Annison et al. 1967). Nevertheless, there is no doubt that triacylglycerols in the form of lipoproteins (chylomicrons and VLDL) are the more important lipid substrate for the mammary gland.

There is comparatively little information on the transport of substrates into mammary gland epithelial cells, but where it exists (e.g. amino acid transport; Neville et al. 1980) the mechanisms involved are similar to those in other tissues. Burnol et al. (1990) have shown that the glucose transporter in the lactating mammary gland is GLUT1 rather than the insulin-sensitive GLUT4. This suggests that glucose entry is not directly regulated by insulin in this tissue, although administration of the hormone in vivo relieves the depressed transport of 3-0-methylglucose into mammary glands of starved lactating rats (Threadgold \& Kuhn, 1984).

\section{SHORT-TERM REGULATION}

Short-term regulation of substrate utilization by the mammary gland is necessary because the normal daily substrate consumption by the tissue is enormous (Table 3). On a high-carbohydrate diet, lipogenesis from glucose accounts for approximately $50 \%$ of milk fat and for the synthesis of lactose. When the availability of glucose decreases (e.g. in starvation or on a low-carbohydrate high-fat diet) the gland's requirement must be decreased, otherwise hypoglycaemia might result because of depletion of the animal's carbohydrate reserves. Thus, in short-term starvation or after an oral load of fat the rate of lipogenesis and lactose synthesis in the gland decreases and these effects are rapidly reversed on refeeding carbohydrate (Bussmann et al. 1984; Williamson et al. 1984). Similar considerations apply to amino acids (Viña et al. 1983) and triacylglycerols (Oller do Nascimento \& Williamson, 1988) during starvation. The uptake of all substrates is decreased by at least $90 \%$ after $20 \mathrm{~h}$ starvation, with the notable exception of ketone bodies where the decrease is only $65 \%$; these changes are reversed on refeeding (Table 3).

\section{Sites of regulation}

Starvation is accompanied by a large decrease $(70 \%)$ in blood flow to the gland (Jones \& Williamson, 1984; Viña et al. 1987) and this in part explains the decrease in substrate

Table 3. Effects of starvation and refeeding on substrate extraction by lactating mammary gland of the rat

(The results are mean values calculated from the arterio-venous differences and blood flow; for details, see Williamson, 1990)

\begin{tabular}{lccccc}
\hline & \multicolumn{4}{c}{ Substrate extracted (mmol/24 h per total tissue) } \\
\cline { 2 - 6 } State of rats & Glucose & $\begin{array}{c}\text { Amino } \\
\text { acids }\end{array}$ & $\begin{array}{c}\text { Triacyl- } \\
\text { glycerols }\end{array}$ & NEFA & $\begin{array}{c}\text { Ketone } \\
\text { bodies }\end{array}$ \\
\hline Fed & 41.6 & 22.3 & 3.6 & 2.0 & 3.5 \\
Starved $(6 \mathrm{~h})$ & 9.7 & 2.5 & - & - & - \\
Starved $(18-20 \mathrm{~h})$ & 1.5 & 0.6 & 0.24 & 0.22 & - \\
Refed $(2-2.5 \mathrm{~h})$ & 23.4 & 9.1 & - & - & \\
\hline
\end{tabular}

NEFA, non-esterified fatty acids. 
utilization, but in addition there are metabolic changes. Apart from transport into the epithelial cells, the regulatory sites for glucose conversion to lipid are hexokinase $(E C$ 2.7.1.1), phosphofructokinase (EC 2.7.1.11), pyruvate dehydrogenase $(E C 1.2 .4 .1)$ and acetyl-CoA carboxylase ( $E C$ 6.4.1.2). In addition, the pentose phosphate pathway and the malate cycle are important for the generation of reducing equivalents (NADPH). In general, the mechanisms involved appear to be the same as those for other lipogenic tissues (liver and adipose tissue). Specifically, the activation state of the pyruvate dehydrogenase complex and acetyl-CoA carboxylase decreases on starvation or fatfeeding (Baxter \& Coore, 1978; McNeillie \& Zammit, 1982; Munday \& Williamson, 1982) and there is evidence for inhibition of phosphofructokinase and hexokinase (Burnol et al. 1988; Mercer \& Williamson, 1988). In addition, the conversion of glucose to lactose is highly sensitive to food withdrawal (Carrick \& Kuhn, 1978). The main site of regulation of triacylglycerol utilization is the activity of lipoprotein lipase which decreases in starvation, but not on fat-feeding (Oller do Nascimento \& Williamson, 1988). The uptake of 2-amino-[1- $\left.{ }^{14} \mathrm{C}\right]$ isobutyrate (a non-metabolizable amino acid analogue) by isolated secretory cells from mammary glands is decreased on starvation of the rat (Viña et al. 1987; Tedstone et al. 1990) suggesting a change in the activity of the $\mathrm{Na}^{+}$-dependent transporter system for amino acids. The majority of these changes are rapidly reversed on refeeding chow to starved lactating rats (Table 3 ).

\section{Regulatory signals}

The large and relatively rapid changes in substrate utilization in response to changes in nutritional state (Table 3) must be mediated by extracellular signals that are related to the quantity and composition of the diet. An obvious candidate is plasma insulin, which is high during intake of carbohydrate and decreases in starvation or on a high-fat diet. Interestingly, there is relative hypoinsulinaemia during lactation in the rat (Robinson et al. 1978; Flint et al. 1979; Marynissen et al. 1983). This is probably due to a combination of a lower blood glucose (increased consumption by gland; Robinson et al. 1978), a decreased pancreatic $\beta$-cell mass (Marynissen et al. 1983) and increased removal of the hormone by the mammary tissue insulin receptors (Jones et al. 1984). However, plasma insulin shows the expected transient increase when a chow meal is fed to a lactating rat (Mercer \& Williamson, 1986; Page \& Kuhn, 1986). There is now strong evidence that insulin stimulates glucose conversion to lipid at a number of sites (Table 4). In addition, recent work indicates that it also positively regulates lipoprotein lipase activity in mammary tissue and, thus, promotes uptake of plasma triacylglycerols (Table 4; Da Costa \& Williamson, 1994). As yet there is no experimental evidence that insulin controls amino acid uptake into the lactating mammary gland of the rat. Prolactin deficiency, however, does lead to decreased amino acid uptake (Viña et al. 1981). The role of prolactin in the regulation of substrate utilization appears to be that of an auxiliary hormone in that it maintains insulin receptors on mammary gland plasma membranes (Flint, 1982). No hormonal antagonist to insulin has yet been described for this tissue. There are no glucagon receptors on mammary gland plasma membranes (Robson et al. 1984) and, although $\beta$-adrenergic receptors are present, adrenaline does not antagonize insulin action. However, adrenaline is a powerful inhibitor of mammary blood flow in the goat (Linzell, 1960). 
Table 4. Summary of regulation of substrate utilization in lactating mammary gland of the rat

\begin{tabular}{|c|c|c|c|c|c|}
\hline \multirow[b]{2}{*}{ Substrate } & \multirow[b]{2}{*}{$\begin{array}{l}\text { Regulated } \\
\text { process }\end{array}$} & \multicolumn{2}{|c|}{ Extracellular signals } & \multirow[b]{2}{*}{$\begin{array}{l}\text { Intracellular } \\
\text { signals }\end{array}$} & \multirow[b]{2}{*}{ References } \\
\hline & & Insulin & $\begin{array}{l}\text { Ketone } \\
\text { bodies }\end{array}$ & & \\
\hline \multirow[t]{5}{*}{ Glucose } & Transport & Activation & - & - & $\begin{array}{l}\text { Threadgold \& Kuhn } \\
\text { (1984) }\end{array}$ \\
\hline & $\begin{array}{l}\text { Hexokinase } \\
\quad(E C \text { 2.7.1.1) }\end{array}$ & Activation & Inhibition & $\begin{array}{l}\text { Glucose-6- } \\
\text { phosphate } \\
\text { (inhibitor) }\end{array}$ & $\begin{array}{l}\text { Mercer \& Williamson } \\
\text { (1988), Burnol et al. } \\
\text { (1988) }\end{array}$ \\
\hline & $\begin{array}{l}\text { Phosphofructo- } \\
\text { kinase } \\
(E C 2.7 .1 .11)\end{array}$ & Activation & Inhibition & $\begin{array}{l}\text { Citrate } \\
\text { (inhibitor), } \\
\text { fructose-2,6- } \\
\text { bisphosphate } \\
\text { (activator) }\end{array}$ & $\begin{array}{l}\text { Zammit (1979), Ward } \\
\text { \& Kuhn (1985), } \\
\text { Mercer \& } \\
\text { Williamson (1988) }\end{array}$ \\
\hline & $\begin{array}{l}\text { Pyruvate } \\
\text { dehydrogenase } \\
\quad(E C 1.2 .4 .1)\end{array}$ & Activation & Inhibition & $\begin{array}{l}\text { Acetyl-CoA } \\
\text { (inhibitor) }\end{array}$ & $\begin{array}{l}\text { Baxter \& Coore (1978), } \\
\text { Munday \& Williamson } \\
\text { (1981), Kilgour \& } \\
\text { Vernon (1987) }\end{array}$ \\
\hline & $\begin{array}{l}\text { Acetyl-CoA } \\
\text { carboxylase } \\
(E C 6.4 .1 .2)\end{array}$ & Activation & - & - & $\begin{array}{l}\text { Munday \& Williamson } \\
\text { (1987), Burnol et al. } \\
\text { (1988) }\end{array}$ \\
\hline Triacylglycerols & $\begin{array}{l}\text { Lipoprotein } \\
\text { lipase } \\
(E C \text { 3.1.1.34) }\end{array}$ & Activation & - & - & $\begin{array}{l}\text { Da Costa \& Williamson } \\
\text { (1994) }\end{array}$ \\
\hline Amino acids & Uptake & - & Inhibition & - & Viña et al. (1983) \\
\hline
\end{tabular}

The only physiological inhibitory signals so far identified are plasma ketone bodies (Table 4) and NEFA, which both increase in starvation or on fat-feeding. Ketone bodies, and particularly acetoacetate in vitro, can inhibit glucose utilization and this is reversed by insulin (see Robinson \& Williamson, 1980). Administration of ketone bodies decreases glucose (Robinson \& Williamson, 1980) and amino acid (Viña et al. 1983) utilization in vivo. Feeding triacylglycerols rapidly decreases glucose utilization by the lactating gland (Agius \& Williamson, 1980), but it is not certain whether this effect is due to chylomicrons per se or the accompanying increase in plasma NEFA and/or ketone bodies. Again, this inhibition is partially reversed by insulin.

\section{ENERGETICS OF MILK MACRONUTRIENT SYNTHESIS}

Although it has long been established that the lactating mammary gland is a highly active tissue, little attention has been paid to its oxidative metabolism. Notable exceptions are the studies of Linzell and his colleagues (see Linzell, 1968) on the lactating goat.

\section{Oxygen uptake}

Measurements of $\mathrm{O}_{2}$ uptake in conscious lactating goats gave mean values of 0.73 $\mu \mathrm{mol} / \mathrm{min}$ per $\mathrm{g}$ (Linzell, 1960) and $0.51 \mu \mathrm{mol} / \mathrm{min}$ per $\mathrm{g}$ (Reynolds, 1967). The $\mathrm{O}_{2}$ 
Table 5. Oxygen uptake by lactating mammary gland of the rat

(Values are means with their standard errors)

\begin{tabular}{|c|c|c|c|c|c|}
\hline \multirow{2}{*}{$\begin{array}{l}\text { Mammary gland } \\
\text { preparation }\end{array}$} & \multicolumn{2}{|c|}{$\begin{array}{c}\text { Arterio-venous } \\
\text { difference }(\mu \mathrm{mol} / \mathrm{ml})\end{array}$} & \multicolumn{2}{|c|}{$\begin{array}{c}\mathrm{O}_{2} \text { uptake } \dagger \\
(\mu \mathrm{mol} / \mathrm{min} \text { per } \mathrm{g})\end{array}$} & \multirow[b]{2}{*}{ References } \\
\hline & Mean & SEM & Mean & SEM & \\
\hline Slices & - & - & 0.69 & - & Folley \& French (1949) \\
\hline Perfused & - & - & 0.53 & - & Clegg \& Calvert (1988) \\
\hline \multirow{2}{*}{$\begin{aligned} \text { In vivo: } & \text { Fed }(n 6) \\
& \text { Starved } 24 \mathrm{~h}(n 4)\end{aligned}$} & $3 \cdot 43$ & $0 \cdot 17$ & $2 \cdot 06$ & $0 \cdot 10$ & \multirow{2}{*}{ Present work } \\
\hline & $2 \cdot 61$ & $0 \cdot 38$ & $0 \cdot 52^{* * *}$ & $0 \cdot 076$ & \\
\hline
\end{tabular}

Mean value was significantly different from that for in vivo fed rats: $* * * P<0 \cdot 001$.

$\dagger$ Blood $\mathrm{O}_{2}$ was measured with a co-oximeter. Mammary gland blood flows used for the calculations of uptake were means of published values (Chatwin et al. 1969; Hanwell \& Linzell, 1973; Jones \& Williamson, 1984; Viña et al. 1987).

uptake is approximately $50 \%$ lower in non-lactating goats. For comparison we have measured $\mathrm{O}_{2}$ uptake by mammary glands of anaesthetized rats (Table 5). The uptake on a per $\mathrm{g}$ tissue basis is considerably higher than those in the goat or in preparations of rat mammary gland in vitro and decreases by $75 \%$ in the starved lactating rat (Table 5) where milk production has virtually ceased and substrate extraction is greatly decreased (Table 3). The difference in $\mathrm{O}_{2}$ uptake between the mammary glands of fed and starved lactating rats $\left(1.54 \mu \mathrm{mol} \mathrm{O} / \mathrm{min}\right.$ per g tissue; Table 5) presumably represents the $\mathrm{O}_{2}$ required for the processes associated with substrate transport, synthesis of milk components, transport of the ionic components $\left(\mathrm{Ca}^{++}, \mathrm{Na}^{+}, \mathrm{K}^{+}\right)$and milk secretion in the fed state.

\section{ATP requirement}

It is instructive to calculate the theoretical amount of ATP required within the gland for the daily synthesis of milk $(50 \mathrm{ml})$ of typical composition $(\mathrm{g} / 1$; lactose 44 , protein 90 , lipid 92) from a chow-fed lactating rat (Table 6). Protein synthesis has by far the major requirement for ATP, exceeding lactose synthesis and uptake of exogenous lipid by nearly an order of magnitude (Table 6). The point of interest is that lipogenesis from glucose is an energy-yielding process (Flatt, 1970). The amount of ATP gained depends on the relative flow of glucose- $\mathrm{C}$ through the pentose phosphate pathway and the malate cycle and ranges from one to five ATP equivalents per acetyl-CoA from glucose incorporated into fatty acid; we have used a value of three ATP equivalents (Table 6). There is net utilization of ATP equivalents (in the form of reduced nicotinamide adenine nucleotide) for lipogenesis from quantitatively less important substrates (e.g. lactate, acetoacetate, leucine). If the secretory pool of triacylglycerol (in the mammary gland) undergoes lipolysis and re-esterification, as is the case in liver (Wiggins \& Gibbons, 1992), then there would be an additional requirement of seven ATP per mol triacylglycerol reformed (Elia et al. 1987). However, present evidence suggests this process proceeds at a slow rate in mammary tissue (D. H. Williamson, unpublished results). When glucose-C provides $50 \%$ of the milk lipid as in Table 6 , example A (highcarbohydrate diet), the ATP produced virtually balances that required for protein 
Table 6. Energetics of synthesis of milk macronutrients in the lactating mammary gland of the rat

(Example $\mathrm{A}$ is a typical composition and yield of milk from a rat on a high-carbohydrate (chow) diet (Roberts \& Coward, 1985); example B is for a high-fat diet. The daily requirement for ATP for synthesis has been calculated as follows: three ATP per lactose (Kuhn \& White, 1977); four ATP per peptide bond; two ATP per non-esterified fatty acid activated. It is assumed that lipogenesis from glucose produces three ATP per acetyl group incorporated into a $C_{10}$ medium-chain fatty acid (see p. 171). The values for lipogenesis have been corrected by subtraction of ATP required for activation of the medium-chain fatty acid)

\begin{tabular}{lccccc}
\hline \hline & \multicolumn{2}{c}{ Example A } & & \multicolumn{2}{c}{ Example B } \\
& $\begin{array}{c}\text { Synthesis } \\
(\mathrm{g} / 24 \mathrm{~h})\end{array}$ & $\begin{array}{c}\text { ATP } \\
(\mathrm{mmol} / 24 \mathrm{~h})\end{array}$ & & $\begin{array}{c}\text { Synthesis } \\
(\mathrm{g} / 24 \mathrm{~h})\end{array}$ & $\begin{array}{c}\text { ATP } \\
(\mathrm{mmol} / 24 \mathrm{~h})\end{array}$ \\
\hline Lactose & $2 \cdot 2$ & -18 & & $2 \cdot 2$ & -18 \\
Protein & $4 \cdot 5$ & -150 & & $4 \cdot 5$ & -150 \\
Lipid: Lipogenesis & $2 \cdot 3$ & +139 & & $0 \cdot 2$ & +14 \\
Exogenous uptake & $2 \cdot 3$ & -16 & & $4 \cdot 4$ & -31 \\
& Balance & -45 & & & -185 \\
\hline
\end{tabular}

synthesis. However, in example B (a high-fat diet), where glucose provides only $4 \%$ of the milk lipid, the production of ATP is only $10 \%$ that required for protein synthesis. In this situation other substrates must be oxidized and likely candidates are NEFA, ketone bodies and certain amino acids (alanine, threonine and glutamine) which are taken up by the gland in excess of the proportion of those amino acids required for casein synthesis. Thus, the $\mathrm{O}_{2}$ extraction by the lactating mammary gland depends on a number of factors including blood flow, amount of glucose utilized for lipogenesis compared with other substrates, and rate of milk secretion. As one might expect from the previous discussion, there is a correlation in the goat between $\mathrm{O}_{2}$ uptake and milk secretion (Linzell, 1960; Reynolds, 1967).

\section{CONCLUSION}

This is a brief review of the regulation of substrate utilization by the mammary gland at peak lactation. While the pathways of synthesis of the major components of milk are broadly understood, many aspects of lactation and its regulation need clarification, for example, how blood flow to the gland is controlled and whether changes in blood flow precede alterations in substrate utilization or vice versa; the contribution of substrate cycling to the high $\mathrm{O}_{2}$ consumption of the gland; the processes that determine the relative proportions of lipid, lactose and protein in milk. Clearly, this metabolically versatile tissue does not deserve its Cinderella image.

The authors thank Mrs M. Barber for careful preparation of the typescript. D.H.W. was a member of Medical Research Council (U.K.) External Scientific Staff.

\section{REFERENCES}

Agius, L. \& Williamson, D. H. (1980). Rapid inhibition of lipogenesis in vivo in lactating rat mammary gland by medium or long-chain triacylglycerols and partial reversal by insulin. Biochemical Journal 192, 361-364. 
Annison, E. F., Linzell, J. L., Fazakerley, S. \& Nichols, B. W. (1967). The oxidation and utilization of palmitate, stearate, oleate and acetate by the mammary gland of the fed goat in relation to their overall metabolism, and the role of plasma phospholipids and neutral lipids in milk-fat synthesis. Biochemical Journal 102, 637-647.

Bauman, D. E. \& Currie, W. B. (1980). Partitioning of nutrients during pregnancy and lactation: a review of mechanisms involving homeostasis and homeorhesis. Journal of Dairy Science 63, 1514-1529.

Baxter, M. A. \& Coore, H. G. (1978). The mode of regulation of pyruvate dehydrogenase of lactating rat mammary gland. Effects of starvation and insulin. Biochemical Journal 174, 553-561.

Buckley, B. M. \& Williamson, D. H. (1977). Origins of blood acetate in the rat. Biochemical Journal 166, 539-545.

Burnol, A.-F., Ebner, S., Ferré, P. \& Girard, J. (1988). Regulation by insulin of glucose metabolism in mammary gland of anaesthetized lactating rats. Stimulation of phosphofructokinase-1 by fructose 2,6-bisphosphate and activation of acetyl-CoA carboxylase. Biochemical Journal 254, 11-14.

Burnol, A.-F., Ferré, P., Leturque, A. \& Girard, J. (1987). Effect of insulin on in vivo glucose utilization in individual tissues of anesthetized lactating rats. American Journal of Physiology 252, E183-E188.

Burnol, A.-F., Leturque, A., Loizeau, M., Postic, C. \& Girard, J. (1990). Glucose transporter expression in rat mammary gland. Biochemical Journal 270, 277-279.

Bussmann, L. E., Ward, S. \& Kuhn, N. J. (1984). Lactose and fatty acid synthesis in lactating-rat mammary gland. Effects of starvation, re-feeding and administration of insulin, adrenaline, streptozotocin and 2-bromo- $\alpha$-ergocryptine. Biochemical Journal 219, 173-180.

Carrick, D. T. \& Kuhn, N. J. (1978). Diurnal variation and response to food withdrawal of lactose synthesis in lactating rats. Biochemical Journal 174, 319-325.

Chatwin, A. L., Linzell, J. L. \& Setchell, B. P. (1969). Cardiovascular changes during lactation in the rat. Journal of Endocrinology 44, 247-254.

Clegg, R. A. \& Calvert, D. T. (1988). An 'in situ' perfusion system suitable for investigating mammary-tissue metabolism in the lactating rat. Hormonal regulation of acetyl-CoA carboxylase. Biochemical Journal 249, 771-777.

Craft, I. L. (1970). The influence of pregnancy and lactation on the morphology and absorptive capacity of the rat small intestine. Clinical Science 38, 287-295.

Cripps, A. W. \& Williams, V. J. (1975). The effect of pregnancy and lactation on food intake, gastrointestinal anatomy and the absorptive capacity of the small intestine in the albino rat. British Journal of Nutrition 33, 17-32.

Da Costa, T. H. M. \& Williamson, D. H. (1994). Regulation of rat mammary-gland uptake of orally administered $\left[1-{ }^{14} \mathrm{C}\right]$ triolein by insulin and prolactin: evidence for bihormonal control of lipoprotein lipase activity. Biochemical Journal 300, 257-262.

Elia, M., Zed, C., Neale, G. \& Livesey, G. (1987). The energy cost of triglyceride-fatty acid recycling in nonobese subjects after an overnight fast and four days of starvation. Metabolism 36, 251-255.

Fell, B. F., Smith, K. A. \& Campbell, R. M. (1963). Hypertrophic and hyperplastic changes in the alimentary canal of the lactating rat. Journal of Pathology and Bacteriology 85, 179-188.

Flatt, J. P. (1970). Conversion of carbohydrate to fat in adipose tissue: an energy-yielding and, therefore, self-limiting process. Journal of Lipid Research 11, 131-143.

Flint, D. J. (1982). Regulation of insulin receptors by prolactin in lactating rat mammary gland. Journal of Endocrinology 93, 279-285.

Flint, D. J., Sinnet-Smith, P. A., Clegg, R. A. \& Vernon, R. G. (1979). Role of insulin receptors in the changing metabolism of adipose tissue during pregnancy and lactation in the rat. Biochemical Journal 182 , 421-427.

Folley, S. J. \& French, T. H. (1949). Intermediary metabolism of mammary gland; respiration of lactating mammary gland slices in presence of carbohydrate. Biochemical Journal 45, 117-125.

Hanwell, A. \& Linzell, J. L. (1973). The effects of engorgement with milk and of suckling on mammary blood flow in the rat. Journal of Physiology 233, 111-125.

Hawkins, R. A. \& Williamson, D. H. (1972). Measurements of substrate uptake by mammary gland of the rat. Biochemical Journal 129, 1171-1173.

Jones, R. G., Ilic, V. \& Williamson, D. H. (1984). Physiologicai significance of altered insulin metabolism in the conscious rat during lactation. Biochemical Journal 220, 455-460.

Jones, R. G. \& Williamson, D. H. (1984). Alterations in mammary-gland blood flow and glucose metabolism in the lactating rat induced by short-term starvation and refeeding. Bioscience Reports 4, 421-426. 
Kilgour, E. \& Vernon, R. G. (1987). Tissue-specific changes in the ability of insulin and noradrenaline to activate pyruvate dehydrogenase in vivo during lactation in the rat. Biochemical Journal 243, 69-74.

Kuhn, N. J. \& White, A. (1977). The role of nucleoside-diphosphatase in a uridine nucleotide cycle associated with lactose synthesis in rat mammary-gland Golgi apparatus. Biochemical Journal 168, 423-433.

Linzell, J. L. (1960). Mammary-gland blood flow and oxygen, glucose and volatile fatty acid uptake in the conscious goat. Journal of Physiology 153, 492-507.

Linzell, J. L. (1968). The magnitude and mechanisms of the uptake of milk precursors by the mammary gland. Proceedings of the Nutrition Society 27, 44-52.

Linzell, J. L. (1974). Mammary blood flow and methods of identifying and measuring precursors of milk. In Lactation, A Comprehensive Treatise, vol. 1, pp. 143-225 [B. L. Larson and V. R. Smith, editors]. New York and London: Academic Press.

Linzell, J. L., Mepham, T. B., Annison, E. F. \& West, C. E. (1969). Mammary metabolism in lactating sows: arteriovenous differences of milk precursors and the mammary metabolism of $\left[{ }^{14} \mathrm{C}\right] \mathrm{glucose}$ and $\left[{ }^{14} \mathrm{C}\right]$ lactate. British Journal of Nutrition 23, 319-332.

McNeillie, E. M. \& Zammit, V. A. (1982). Regulation of acetyl-CoA carboxylase in rat mammary gland. Effects of starvation and of insulin and prolactin deficiency on the fraction of the enzyme in the active form in vivo. Biochemical Journal 204, 273-280.

Marynissen, G., Aerts, L. \& Van Assche, F. A. (1983). The endocrine pancreas during pregnancy and lactation in the rat. Journal of Developmental Physiology 5, 373-381.

Mercer, S. W. \& Williamson, D. H. (1986). Time-course of changes in plasma glucose and insulin concentrations and mammary-gland lipogenesis during re-feeding starved conscious lactating rats. Biochemical Journal 239, 489-492.

Mercer, S. W. \& Williamson, D. H. (1988). Rapid inhibition by intragastric triolein of the reactivation of glucose utilization and lipogenesis in the mammary gland during the starved-refed transition in lactating rats. Evidence for a direct effect of oral lipid on mammary tissue. Biochemical Journal 250, 269-276.

Munday, M. R. \& Williamson, D. H. (1981). Role of pyruvate dehydrogenase and insulin in the regulation of lipogenesis in the lactating mammary gland of the rat during the starved-refed transition. Biochemical Journal 196, 831-837.

Munday, M. R. \& Williamson, D. H. (1982). Effects of starvation, insulin or prolactin deficiency on the activity of acetyl-CoA carboxylase in mammary gland and liver of lactating rats. FEBS Letters 138, 285-288.

Munday, M. R. \& Williamson, D. H. (1987). Insulin activation of lipogenesis in isolated mammary acini from lactating rats fed on a high-fat diet. Evidence that acetyl-CoA carboxylase is a site of action. Biochemical Journal 242, 905-911.

Neville, M. C., Lobitz, C. J., Ripoll, E. A. \& Tinney, C. (1980). The sites for $\alpha$-aminoisobutyric acid uptake in normal mammary gland and ascites tumor cells. A comparative study of mouse tissues in vitro. Journal of Biological Chemistry 255, 7311-7316.

Oller do Nascimento, C. M. \& Williamson, D. H. (1986). Evidence for conservation of dietary lipid in the rat during lactation and the immediate period after removal of the litter. Decreased oxidation of oral $\left[1-{ }^{14}\right.$ C]triolein. Biochemical Journal 239, 233-236.

Oller do Nascimento, C. M. \& Williamson, D. H. (1988). Tissue-specific effects of starvation and refeeding on the disposal of oral $\left[1-{ }^{14} \mathrm{C}\right]$ triolein in the rat during lactation and on removal of litter. Biochemical Journal 254, 539-546.

Page, T. \& Kuhn, N. J. (1986). Arteriovenous glucose differences across the mammary gland of the fed, starved, and re-fed lactating rat. Biochemical Journal 239, 269-274.

Reynolds, M. (1967). Mammary respiration in lactating goats. American Journal of Physiology 212, 707-710.

Roberts, S. B. \& Coward, W. A. (1985). Dietary supplementation increases milk output in the rat. British Journal of Nutrition 53, 1-9.

Robinson, A. M., Girard, J. R. \& Williamson, D. H. (1978). Evidence for a role of insulin in the regulation of lipogenesis in lactating rat mammary gland. Measurements of lipogenesis in vivo and plasma hormone concentrations in response to starvation and refeeding. Biochemical Journal 176, 343-346.

Robinson, A. M. \& Williamson, D. H. (1980). Physiological roles of ketone bodies as substrates and signals in mammalian tissues. Physiological Reviews 60, 143-187.

Robson, N. A., Clegg, R. A. \& Zammit, V. A. (1984). Regulation of peripheral lipogenesis by glucagon. Inability of the hormone to inhibit lipogenesis in rat mammary acini in vitro in the presence or absence of agents which alter its effects on adipocytes. Biochemical Journal 217, 743-749.

Spincer, J., Rook, J. A. F. \& Towers, K. G. (1969). The uptake of plasma constituents by the mammary gland of the sow. Biochemical Journal 111, 727-732. 
Tedstone, A. E., Ilic, V. \& Williamson, D. H. (1990). Reciprocal changes in amino acid metabolism in mammary gland and liver of the lactating rat on starvation and refeeding as indicated by the tissue accumulation of $\alpha$-amino[1-14 C]isobutyrate. Biochemical Journal 268, 799-802.

Threadgold, L. C. \& Kuhn, N. J. (1984). Monosaccharide transport in the mammary gland of the intact lactating rat. Biochemical Journal 218, 213-219.

Vernon, R. G., Faulkner, A., Hay, W. W. Jr, Calvert, D. T. \& Flint, D. J. (1990). Insulin resistance of hind-limb tissues in vivo in lactating sheep. Biochemical Journal 270, 783-786.

Viña, J., Puertes, I. R., Saez, G. T. \& Viña, J. R. (1981). Role of prolactin in amino acid uptake by the lactating mammary gland of the rat. FEBS Letters 126, 250-252.

Viña, J. R., Puertes, I. R., Montoro, J. B. \& Viña, J. (1983). Effect of starvation and refeeding on amino acid uptake by mammary gland of the lactating rat. Role of ketone bodies. Biochemical Journal 216, 343-347.

Viña, J. R., Puertes, I. R., Rodriguez, A., Saez, G. T. \& Viña, J. (1987). Effect of fasting on amino acid metabolism by lactating mammary gland. Studies in women and rats. Journal of Nutrition 117, 533-538.

Ward, S. \& Kuhn, N. J. (1985). Role of fructose 2,6-bisphosphate in mammary gland of fed, starved and re-fed lactating rats. Biochemical Journal 232, 931-934.

Wiggins, D. \& Gibbons, G. F. (1992). The lipolysis/esterification cycle of hepatic triacylglycerol. Its role in the secretion of very-low-density lipoprotein and its response to hormones and sulphonylureas. Biochemical Journal 284, 457-462.

Williamson, D. H. (1980). Integration of metabolism in tissues of the lactating rat. FEBS Letters 117, K86-K92.

Williamson, D. H. (1984). The regulation of substrate utilization. Clinical Nutrition 2, 129-136.

Williamson, D. H. (1990). The lactating mammary gland of the rat and the starved-refed transition: a model system for the study of the temporal regulation of substrate utilization. Biochemical Society Transactions $\mathbf{1 8}$, $853-856$.

Williamson, D. H., Evans, R. D. \& Wood, S. C. (1988). Tumor growth and lipid metabolism during lactation in the rat. In Advances in Enzyme Regulation, vol. 27, pp. 93-104 [G. Weber, editor]. Oxford and New York: Pergamon Press.

Williamson, D. H., Munday, M. R. \& Jones, R. G. (1984). Biochemical basis of dietary influences on the synthesis of the macronutrients of rat milk. Federation Proceedings 43, 2443-2447.

Zammit, V. A. (1979). Effects of citrate on phosphofructokinase from lactating rat mammary gland acini. FEBS Letters 108, 193-196. 